\title{
Book Review: Lessons of War
}

Ronald J. Koshes, MD

Walter Reed Army Medical Center, Washington DC

Follow this and additional works at: https://jdc.jefferson.edu/jeffjpsychiatry

Part of the Psychiatry Commons

Let us know how access to this document benefits you

\section{Recommended Citation}

Koshes, MD, Ronald J. (1988) "Book Review: Lessons of War," Jefferson Journal of Psychiatry. Vol. 6 : Iss. 2 , Article 13.

DOI: https://doi.org/10.29046/JJP.006.2.013

Available at: https://jdc.jefferson.edu/jeffjpsychiatry/vol6/iss2/13

This Article is brought to you for free and open access by the Jefferson Digital Commons. The Jefferson Digital Commons is a service of Thomas Jefferson University's Center for Teaching and Learning (CTL). The Commons is a showcase for Jefferson books and journals, peer-reviewed scholarly publications, unique historical collections from the University archives, and teaching tools. The Jefferson Digital Commons allows researchers and interested readers anywhere in the world to learn about and keep up to date with Jefferson scholarship. This article has been accepted for inclusion in Jefferson Journal of Psychiatry by an authorized administrator of the Jefferson Digital Commons. For more information, please contact: JeffersonDigitalCommons@jefferson.edu. 


\title{
Book Reviews
}

\section{Lessons of War}

\author{
MILITARY PSYCHIATRY: A COMPARATIVE PERSPECTIVE \\ Richard A. Gabriel, editor \\ New York, The Greenwood Press \\ 1986, 170 pages \\ Ronald J. Koshes, M.D.
}

The lessons of combat psychiatry have sometimes been quickly forgotten after the war has ended. Denial of the serious nature of armed conflict and its effects on the lives of the human beings waging war may be a part of the reason why Military Psychiatry: A Comparative Perspective needed to be written. Richard A. Gabriel, who edits this short volume, states explicitly the construct on which the book is based: “. . . (O)ne of the most important elements in the equation of an army's combat effectiveness is how well soldiers stand up to the horrors of battle . . human beings are very fragile (and) no one is immune to battle stress." Even death and maiming which are traditionally cited as the cause of the downfall of armies can lead to psychiatric breakdown. Psychiatric debilitation is perhaps a worse, but treatable, destructive force. War, which has become more intense, destructive, lethal and brief, promises greater numbers of a different type of psychiatric casualty than that seen in relatively slow-paced terrain troop warfare. In the 1973 Yom Kippur War, 30-50 percent of the total number of casualties were psychiatric. This was a quick, intense conflict and the Israeli military psychiatrists were generally unprepared in terms of psychiatric support facilities for the degree of acute battle reactions they encountered.

Dr. Gabriel has brought together the ideas of a group of experts in the field of combat psychology in his panel of international psychiatrists. The book is well designed to first provide an understanding of the human dimension of combat breakdown and the necessary limitations which the "fragility" of the mind places on technological warfare. He warns: "At a near point in the future, if, indeed, we have not already reached it, war may become obsolete. That is, the practice of warfare may become impossible for the human being to perform. The limits of warfare are already clear, and chief among them is the ability of human beings to remain sane and functional amid the storm of horror that battle necessarily entails."

The chapters which provide an examination of the historical development and effectiveness of military psychiatry in the American, Soviet, German and 
Israeli Armies are indeed the most interesting. These Armies are in many ways models of a detailed doctrine and practice for dealing with psychiatric casualties. Their emphasis in training in combat psychiatry confirms the notion that the mental health of soldiers fighting a battle is multideterminate and important in the integrity of the overall fighting force.

The concluding chapter, by Dr. Franklin D. Jones, a recently retired senior Army psychiatrist, addresses the question of whether our previously used methods of preventing and treating combat stress will be effective in our next wars if they are of high-intensity. His analysis of the ineffectiveness of the traditional principles of forward treatment in a high-technological battle is challenging. Refuge, available therapists, rest, and anticipated return to the unit would be nearly impossible in a highly mobile, intense battle situation. The psychological pressures of anticipated and quick, unpredictable annihilation could spark an Army's total disability unless new principles of prevention and treatment are implemented. These would include realistic training to decrease "green troop casualties," use of fellow soldiers and specially trained medics to treat psychiatric casualties in the midst of battle and the possible use of non-sedating anti-anxiety drugs. This last chapter has a poignancy which not only openly argues for psychiatric training and preparation, but also implicitly for solutions in place of battle.

Overall, this book is easily readable and fluent, qualities which, if absent, can be the most annoying features of a compendium. Dr. Gabriel and his contributors have produced a coherent volume which emphasizes the lessons of military psychiatry learned in war and addresses the denial of the need for psychiatric prepartion for war by looking at important and yet sometimes neglected questions. 